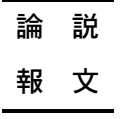

\section{ヒ素除去装置の污泥槽内の微生物による 七素のメチル化に関する研究}

\title{
A Study on Arsenic Methylation by Microorganisms in Sludge Tank of Arsenic Removal Unit
}

\author{
Munetoshi MIYATAKE ${ }^{1}$ and Sachio HAYASHI ${ }^{1}$
}

${ }^{1}$ Department of Applied Chemistry, University of Miyazaki, Miyazaki 889-2192, Japan

\begin{abstract}
An arsenic removal unit was constructed by the Miyazaki University research group in Bangladesh. The sludge drained from the arsenic removal unit was directed to a sludge tank and allowed to settle down. Then the supernatant in the tank was released to an artificial pond. Biomethylation of arsenic is usually considered as a detoxification of arsenic because toxicity of most organic methylated arsenic is much less than that inorganic arsenic. Microorganisms in the sludge tank were evaluated growth characteristics and arsenic methylation. As a result, dimethylarsinic acid was detected in the broth, and the amount of total arsenic compounds in the broth decreased. It is thought that this loss was contributed by biogenic activity induced by inorganic arsenic biomethylation to gasified volatile organic species, such as monomethylarsine and dimethylarsine. These results suggested that microorganisms in the sludge tank may be utilized for natural attenuation of arsenic sludge from the arsenic removal unit.
\end{abstract}

Key words: Arsenic methylation, Organic methylated arsenic, Biologic gasification, Microorganisms

\section{1. 緒言}

ヒ素による地下水の污染は世界各地に広がって扣り, 七素による重大な健康被害が数多く報告されている ${ }^{1-4}$ 。 特にバングラデシュは国土の 8 割の土壌が高濃度の七素 を含んで扣り，それによる地下水污染は深刻で 5,000 万 人以上の住民が七素に污染された地下水を飲んでいる と言われている ${ }^{5-8}$ 。現在, 宮崎大学の研究グループで開 発した 4 基のコミュニティ用ヒ素除去装置がバングラデ シュで稼動して扣り，安全な水を地域住民に供給してい る9 。素除去装置は 5 価の七素と 3 価の鉄が吸着・共沈 する性質を利用したものである。地下水中に含まれる七 素と鉄を酸化し共沈させ，共沈物を砂利槽でトラップす ることで匕素を除去している。これらの装置に拈いて, 常にヒ素濃度の低い安全な水を供給するためには，砂利 槽が目詰まりを起こす前にヒ素污泥（七素・鉄共沈物） を引き抜く必要がある。現地では，砂利槽に設置された

キーワード：ヒ素のメチル化, メチル化有機七素, 生物 学的ガス化, 微生物

1 宮崎大学工学部物質環境化学科

平成 23 年 9 月 3 日受理

*e-mail: t0g205u@cc.miyazaki-u.ac.jp
排水バルブを定期的に開けたり, 砂利層内の砂利を洗浄 したりすることにより, ヒ素除去機能を維持しているが, 排出される砂利槽の污泥と砂利洗浄水の処理方法が問 題となっている ${ }^{10}$ 。それらの処理方法を確立するため, 2004 年から排出された污泥や洗浄水は沈殿処理のため 污泥槽に溜められ，その上澄み液は人工池に放流されて いる。污泥槽内で沈殿した污泥に関しては, セメントに よる固化での処分方法が検討されている。人工池に関し ては, 生物機能を利用した自然浄化処理が試みられてい る。污泥のセメント固化処分では，セメントを $2 \%$ 添加 した場合に土壌污染対策法に基づく污染基準である第二 溶出基準をクリアーすることが分かった。一方人工池で は, 污泥槽の上澄み液に $0.1 \mathrm{mg} / 1$ 以上の七素が含まれて おり，人工池への放流が長期間続くと人工池内の七素の 蓄積がかなりの量になることが予想され, 蓄積したヒ素 の処理が問題となっている ${ }^{11}$ 。

一般にヒ素の毒性はその化学形態によって異なり, 無 機七素に比べ有機ヒ素化合物は極めて毒性が低いことが 知られている。そのため, 微生物によるヒ素のメチル化 は七素の毒性の低減化に有効な手段として考えられてい る。これまで, 七素をメチル化する微生物は嫌気性菌に よるモノメチルアルシン (MMA) やジメチルアルシン 
（DMA）のよらな揮発性有機七素化合物を生成するもの が数多く報告されており ${ }^{12-14}$, それらの微生物の機能を 利用して，無機七素を揮発性の有機七素化合物に変換す ることで, 污染土㙥中のヒ素の気化による浄化が検討さ れている15。

そこで, 污泥槽内での七素処理の効率化を図り, 人工 池へのヒ素の流出量の軽減を目的として, 污泥槽で行 なっているヒ素の沈殿処理に加え, 生物機能を利用して 毒性の高い無機七素をメチル化し毒性の低い揮発性のメ チル化有機七素化合物に変換することで，七素の毒性の 低減化を図った上でヒ素を気化させ大気中に拡散させる ことが可能かどらかを調べることにした。本研究では, 污泥槽内の微生物による七素のメチル化について検討 し, さらにヒ素のメチル化を促進させ污泥中の無機七素 をより多くメチル化有機ヒ素化合物に変換させるため に, ヒ素メチル化細菌を污泥中の微生物と一緒に培養を 行なったので，以下に報告する。

\section{2. 実験方法}

\section{1 試料}

污泥はバングラデシュのジェソール県マルア村に設置 されたヒ素除去装置の活泥槽より採取されたものを用い た。污泥を採取したときの污泥槽内の沈殿物の上部の表 層水の $\mathrm{pH}(\mathrm{DKK} \cdot \mathrm{TOA} \mathrm{HM}-20 \mathrm{P})$ は 7.6, 酸化還元電位 （DKK·TOA RM-20P）は $198 \mathrm{mV}$ であり酸化状態であっ た。表層水の七素濃度は $0.131 \mathrm{mg} / 1$ で，その内 5 価の七 素は全体の $84.7 \%$ であった。污泥槽内の沈殿物を回収し 污泥とした。滅菌水 $9.0 \mathrm{ml}$ に污泥 $1.0 \mathrm{ml}$ 加え懸濁した後, 上澄み液（pH 7.2）について，ヒ素と鉄の定量分析を行 ない, 生菌数を測定し，培養実験を行なった。

\section{2 生菌数の測定}

一般細菌の生菌数は平板表面塗布法にて行なった。培 地に Nutrient agar（日水製薬）を用いて，希釈した上澄 み液を塗布し $30^{\circ} \mathrm{C} て ゙ 24$ 時間培養した後，コロニー数を 計測した。

\section{3 培養実験}

培地は Nutrient Broth（日水製薬） $3.00 \mathrm{~g} / 1$ にグルコース $1.00 \mathrm{~g} / \mathrm{l}$ ，硝酸アンモニウム $0.500 \mathrm{~g} / \mathrm{l}, \quad \mathrm{L}$-メチオニン 50.0 $\mathrm{mg} / \mathrm{l}$, 乳酸ナトリウム $2.50 \mathrm{~g} / \mathrm{l}$, ビタミン $\mathrm{B}_{12} 0.500 \mathrm{mg} / \mathrm{l}$ を 添加したもの（pH 5.8）を使用した。ヒ素は 3 価のヒ素 (As(III)）として亜ヒ酸ナトリウム（和光純薬）を，5 価 のヒ素 $(\mathrm{As}(\mathrm{V}))$ としてヒ酸二ナトリウム（和光純薬）を ヒ素濃度が $0.100 \mathrm{mg} / \mathrm{l}$ になるように添加した。

培養実験は上澄み液を培地に $2.0 \mathrm{v} / \mathrm{v} \%$ 加え $30^{\circ} \mathrm{C}$ で 4 日 間培養を行なった。ヒ素メチル化細菌の影響を調べる実 験では, Bacillus cereus R2 株を七素の添加していない培
地で $30^{\circ} \mathrm{C}, 24$ 時間振とう培養した後の培養液を, 上澄 み液 $2.0 \mathrm{v} / \mathrm{v} \%$ 加えた培地に $2.0 \mathrm{v} / \mathrm{v} \%$ 加え $30^{\circ} \mathrm{C}$ で 4 日間 培養を行なった。好気的培養は培地 $100 \mathrm{ml}$ を入れかぶせ 式シリコ栓で蓋をした $500 \mathrm{ml}$ 容振とらフラスコを用い て, 100 strokes/min で振とう培養した。嫌気的培養は培 地 $100 \mathrm{ml}$ をれシリコン栓で蓋をした $100 \mathrm{ml}$ 容メジュー ム瓶を用いて, 上部を窒素で置換した後, 静置培養した。 培養後, 所定の時間培養した培養液を遠心分離 $(10,000 \times \mathrm{g}, 15$ 分間) により, 菌体と培養液上清に分け た。培養液上清はヒ素濃度を形態別に測定した。菌体は 凍結乾燥後, 重量を測定した。菌体中のヒ素量を調べる ために, $2.00 \mathrm{~mol} / \mathrm{l}$ 水酸化ナトリウム水溶液で溶菌処理を 行ない遠心分離 $(10,000 \times \mathrm{g}, 15$ 分間 $)$ 後, 上清の七素濃 度を測定した。

\section{4 分析}

七素の定量分析は形態別に還元気化-超低温捕集-原子 吸光装置（Shimadzu ASA-2sp-Shimadzu AA6650）を用い て測定した。鉄の定量分析はフェナントロリン法により 測定した。全ての実験は 3 回行ない, それぞれの試料に ついて 2 回測定し, 本報に示している結果はそれらの平 均值である。得られた值は全て平均值から $3 \%$ の範囲内 であった。

\section{3. 結果および考察}

\section{1 污泥内のヒ素と鉄濃度および生菌数}

污泥中に可溶化している七素と鉄濃度を調べた結果, ヒ素濃度は $0.286 \mathrm{mg} / \mathrm{l}$, 鉄濃度は $0.1 \mathrm{mg} / \mathrm{l}$ 未満であった。

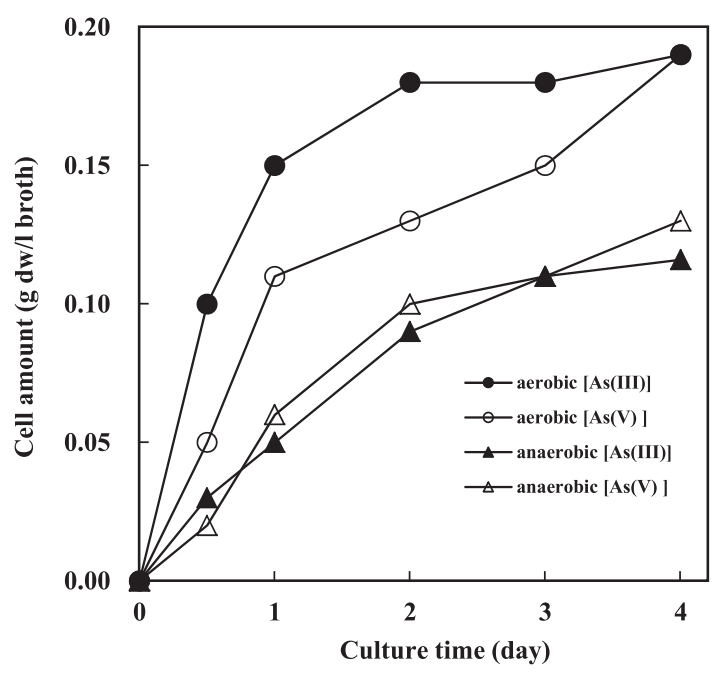

Fig. 1 Effect of arsenic on cell growth. Culture were carried out in the presence of $0.100 \mathrm{mg} \mathrm{As} / \mathrm{l}$ of either As(III) or $\mathrm{As}(\mathrm{V})$ for 4 day at $30^{\circ} \mathrm{C}$. 
またメチル化有機七素を微量検出することが出来た。

污泥内の一般細菌の生菌数は $1.2 \times 10^{7} \mathrm{CFU} / \mathrm{ml}$ であった。

\section{2 菌の増殖に及ぼすヒ素の影響}

污泥中の微生物の増殖に及ぼす七素の影響を調べるた めに, 培地に $\mathrm{As}(\mathrm{III})$ と $\mathrm{As}(\mathrm{V})$ を $0.1 \mathrm{mg} \mathrm{As} / 1$ 添加して好気 的抢よび嫌気的に 4 日間培養した時の乾燥菌体量 (dw) を測定した。得られた值から，上澄み液を培地に加えた 直後, 培養液を採取し遠心分離・凍結乾燥した後の重量 （<0.001 g dw/l broht）を差し引いた結果を Fig. 1 に示す。 好気的に培養した場合, As(III) より As(V)の方が培養 3 日 目までの菌体量が少なく初期の菌の増殖に影響を及ぼし ていることが分かった。一方嫌気的に培養した場合は, $\mathrm{As}(\mathrm{III})$ と $\mathrm{As}(\mathrm{V})$ では違いは見られなかったが，全体的に 好気的培養に比べ菌体量が少なく菌の増殖に差が認めら
れた。また， As(III) と異なり $\mathrm{As}(\mathrm{V})$ を添加した好気的, 嫌気的培養の両方で，培養 3 日目から 4 日目にかけて菌 体量の増加が見られた。

\section{3 ヒ素のメチル化における経時変化}

污泥中の微生物によるヒ素のメチル化について調べる ために，培養液上清中の七素濃度を形態別に測定した結 果を Fig. 2 に示す。その結果, 各々の培養条件に扔いて も培養が進むにつれて無機七素の濃度は減少し続け，特 に好気的培養に拈いて 1 日目から 2 日目にかけて急激に 減少が見られた。無機七素の濃度は好気的培養 4 日目で は As(III), As(V) の両方で $0.009 \mathrm{mg} \mathrm{As} / 1$ 以下まで, 嫌気 的培養 4 日目では $0.037 \mathrm{mg} \mathrm{As} / 1$ 以下まで低下し, 好気的 培養に打いて 3 日目からはジメチルアルシン酸 (DMAA) の濃度を下回った。一方 DMAA は，培養 2 日目からを検
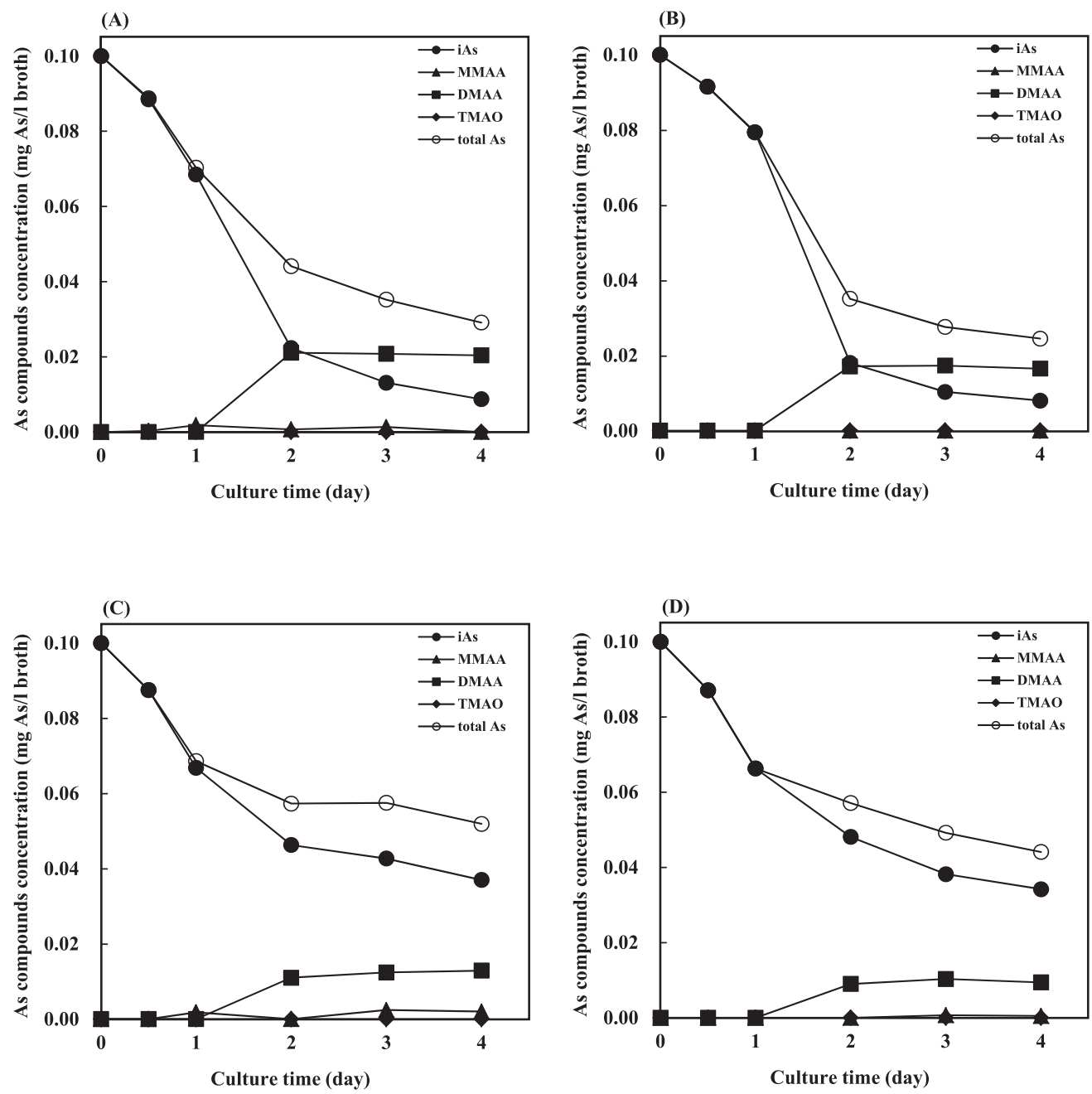

Fig. 2 Time courses of arsenic methylation. Culture were carried out in the presence of $0.100 \mathrm{mg}$ As/l of either As(III) or As(V) for 4 day at $30^{\circ} \mathrm{C}$. (A) Aerobic culture [As(III)]; (B) aerobic culture [As(V)]; (C) anaerobic culture [As(III)]; (D) anaerobic culture $[\mathrm{As}(\mathrm{V})]$. iAs, inorganic arsenic. 
Table 1 Arsenic adsorbed from culture medium of microorganisms after 4 day.

\begin{tabular}{cccc}
\hline \multirow{2}{*}{ Culture (4 day) $\begin{array}{c}\text { Cell amount } \\
\text { (g dw/l broth) }\end{array}$} & \multicolumn{2}{c}{ As adsorption } \\
\cline { 3 - 4 } & 0.19 & 0.036 & 0.0069 \\
\hline $\begin{array}{c}\text { Aerobic } \\
\text { (As }(\mathrm{III})]\end{array}$ & & 0.029 & 0.0056 \\
$\begin{array}{c}\text { Aerobic } \\
\quad \text { As(V)] }\end{array}$ & 0.19 & 0.074 & 0.0089 \\
$\begin{array}{c}\text { Anaerobic } \\
{[\text { As(III)] }}\end{array}$ & 0.12 & 0.058 & 0.0075 \\
$\begin{array}{r}\text { Anaerobic } \\
{[\text { As(V)] }}\end{array}$ & 0.13 & & \\
\hline
\end{tabular}

Culture were carried out in the presence of $0.100 \mathrm{mg} \mathrm{As} / \mathrm{l}$ of either $\mathrm{As}(\mathrm{III})$ or $\mathrm{As}(\mathrm{V})$ at $30^{\circ} \mathrm{C}$.

出することができ2日目から4日目までほぼ一定であり， 好気的培養では $\mathrm{As}(\mathrm{III}), \mathrm{As}(\mathrm{V})$ の両方で $0.016 \mathrm{mg} \mathrm{As} / 1$ 以 上，嫌気的培養では $0.009 \mathrm{mg} \mathrm{As} / 1$ 以上であった。モノメ チルアルソン酸（MMAA）は As(V)を添加した好気的培 養以外でわずかに検出することができた。トリメチルア ルシンオキシド（TMAO）はどの培養条件においても検出 することができなかった。培養液の全七素濃度は初期の 濃度に比べて，各々の培養条件においても培養が進むに つれて減少し続け，As(V) を添加した好気的培養 4 日目 で $24.5 \%$ まで減少した。全七素濃度の減少の割合は嫌気 的培養より好気的培養, $\mathrm{As}(\mathrm{III})$ より $\mathrm{As}(\mathrm{V})$ を添加した場 合の方が高く，菌体量の変化と同じ傾向を示した。この ことは, ヒ素のメチル化に関与した菌が増殖したことや, 培養液中の七素濃度の低下により, 七素に対してあまり耐 性を持たない菌の増殖が活発になったことが考えられる。

\section{4 微生物によるヒ素の吸着}

污泥中の微生物による七素の吸着量を調べるために, 凍結乾燥した菌体に含まれる七素量を測定した。その結 果，培養 2 日目末ではヒ素の吸着量が増加したが，それ 以降はほぼ一定であった。培養 4 日目の結果を Table 1 に 示す。七素の吸着量は初期の七素濃度の 1 割以下であり, As(III) を添加した嫌気的培養で $0.0089 \mathrm{mg} \mathrm{As} / 1$ broth で あった。吸着の割合は好気的培養より嫌気的培養, $\mathrm{As}(\mathrm{V})$ より As(III) を添加した場合の方が高かった。

回収した菌体に 1 割以下の七素しか含まれていなかっ たことから推測すると，微生物の働きにより無機七素が MMAA や DMAA に変換され，さらにMMA や DMA の よらな揮発性のメチル化有機七素化合物に変換されたこ とで, 培養液から気化したのではないかと考えられる。 このことは, 污泥槽内に無機七素を揮発性のメチル化有 機七素化合物に変換することができる微生物の存在を示 唆するものであり，これらの微生物の働きはメチル化に よるヒ素の毒性の低減化を図るとともに，揮発性メチル

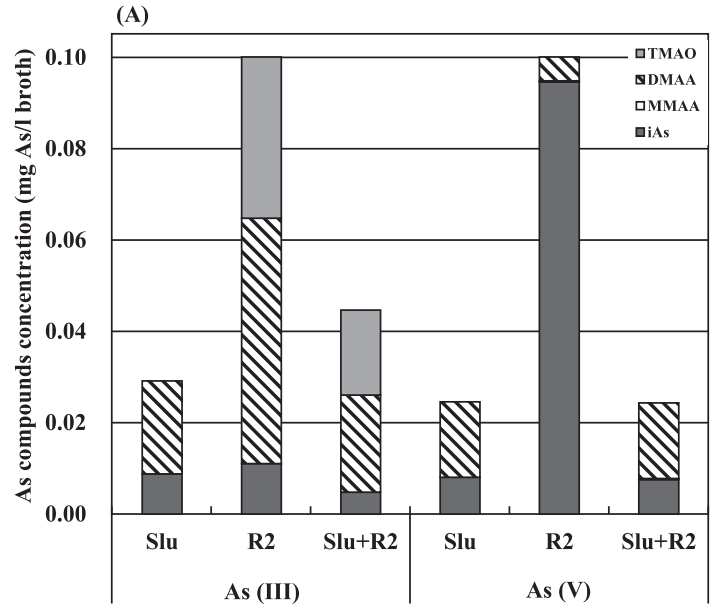

(B)

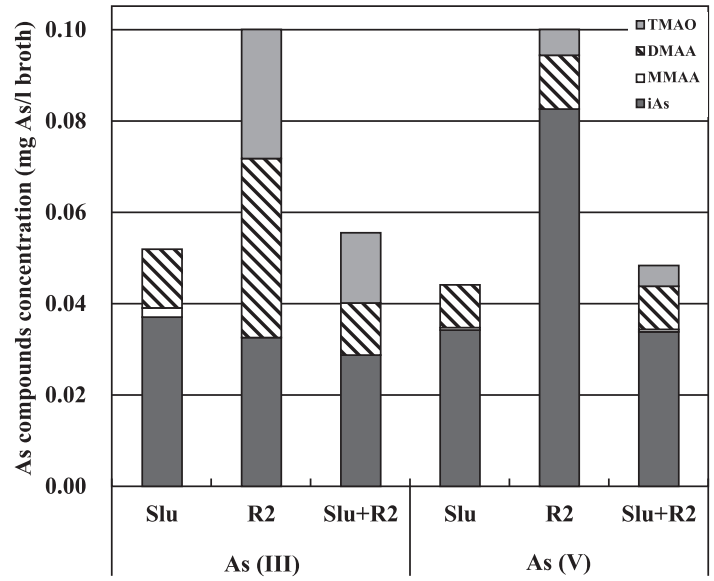

Fig. 3 Effect of arsenic methylating bacterium on arsenic methylation. Culture were carried out in the presence of $0.100 \mathrm{mg} \mathrm{As} / \mathrm{l}$ of either $\mathrm{As}(\mathrm{III})$ or $\mathrm{As}(\mathrm{V})$ for 4 day at $30^{\circ} \mathrm{C}$. (A) Aerobic culture; (B) anaerobic culture. Slu, broth inoculated with supernatant solution of sludge; R2, broth inoculated with $B$. cereus strain R2; Slu + R2, broth inoculated with supernatant solution of sludge and broth of B. cereus strain R2.

化有機七素化合物へ変換することで大気中に気化・拡散 させることを可能にするものである。

\section{5 ヒ素メチル化細菌の影響}

ヒ素メチル化細菌 Bacillus cereus R2 株は, DMAA や TMAOのような非揮発性のメチル化有機七素化合物を産 生することが分かって招り，特に $0.100 \mathrm{mg} \mathrm{As} / 1$ の As(III) を添加した場合に好気的培養時に $89.0 \%$ の割合で無機ヒ 素をメチル化有機ヒ素化合物に変換する ${ }^{16}$ 。無機ヒ素の メチル化を促進させために, R2 株の培養液を培地に加え 污泥内の微生物と一緒に培養を行なった。その結果を Fig. 3 に示す。その結果, 各々の培養条件においても R2 
株を添加した場合, 無機七素の濃度が減少し, 特に As(III) を添加した好気的培養では $0.005 \mathrm{mg} \mathrm{As} / 1$ と, R2 株を添 加していない場合に比べて 54.0\% まで減少した。一方 DMAA は， R2 株を添加した場合でも添加しなかったと きとほぼ同じ程度の濃度を示した。TMAOは $\mathrm{As}(\mathrm{V})$ を添 加した好気的培養以外で, R2 株を添加すると検出するこ とができ，その濃度は As(III) を添加した好気，嫌気的培 養で $0.015 \mathrm{mg} \mathrm{As} / 1$ 以上であった。培養液の全七素濃度は TMAOを検出することができなかった As(V)を添加した 好気的培養以外で, R2 株を添加すると産生した TMAO 分だけ増加した。R2 株を添加することで, 無機ヒ素をよ り多くメチル化有機七素化合物に変化することができ, 七素の毒性の低減化は図れるが, 培養液中の全七素濃度 はR2 株を添加することで増加した。

\section{4. 結言}

七素除去装置の污泥槽内から無機七素を揮発性のメチ ル化有機七素化合物に変換することができる微生物の存 在を確認した。そのため, 培養液中の全七素濃度は初期 の濃度に比べて, 各々の培養条件に拈いて減少したが, 好気や嫌気, 添加するヒ素の形態により違いが生じた。 $\mathrm{As}(\mathrm{V})$ を添加した好気的培養が最も良い結果を示し, 4 日 目で培養液中の全七素濃度は $24.5 \%$, 無機七素の濃度は $0.009 \mathrm{mg} \mathrm{As} / 1$ まで減少した。

ヒ素メチル化細菌と組み合わせると, 毒性の極めて低 いTMAOにも無機七素を変換することができ無機七素の 濃度を下げることができたため，毒性の低減化は図れた が，TMAO 分だけ培養液中の全七素濃度は増加した。こ のことは, 污泥中に TMAOを還元してトリメチルアルシ ンに変換できる微生物が存在しなかったためと考えられ る。

今回, 污泥槽内に蓄積した無機七素を污泥槽内の微生 物の働きによって, 無機ヒ素をメチル化し揮発性のメチ ル化有機七素化合物に変換することで, 污泥内の七素の 毒性の低減化を図った上で七素を気化させ大気中に拡散 させることが可能であることが分かった。このことは, 七素除去装置から排出される七素污泥の処理を考える上
で有用な知見となる。污泥内にメチル化有機七素化合物 を微量しか検出することができなかったことから, 今回 の結果を参考にしながら, 今後これらの有用な微生物の 機能を污泥槽内で発現させていきたい。

\section{References}

1. D. Das, G.B. Samanta, K. Mandal, T.R. Chowdhury, C.R. Chanda, P.P. Chowdhury, G.K. Basu, D. Chakraborti: Geochem. Health, 18, pp. 5-15 (1996)

2. M.F. Hughes: Toxicol. Lett., 133, pp. 1-16 (2002)

3. P.L. Smedley and D.G. Kinniburgh: Appl. Geochem., 17, pp. 517-568 (2002)

4. J.S. Wang and C.M. Wai: J. Chem. Educ., 81, pp. 207213 (2004)

5. R.T. Nickson, J.M. McArthur, W.G. Burgess, K.M. Ahmed, P. Ravenscroft, M. Rahman: Nature, 395, pp. 338 (1998)

6. R.T. Nickson, J.M. McArthur, P. Ravenscroft, W.G. Burgess, K.M. Ahmed: Appl. Geochem., 15, pp. 403413 (2000)

7. K. Tanabe, H. Yokota, H. Hironaka, S. Tsushima, Y. Kubota: J. Organomet. Chem., 15, pp. 241-251 (2001)

8. A. Mushtaque and R. Chowdhury: Scientific Am. Aug., 86-91 (2004)

9. M.M. Hussainuzzaman and H. Yokota: J. ASTM Intern., 3, pp. 1-9 (2006)

10. H. Yokota, K. Tanabe, M. Sezaki, Y. Akiyoshi, T. Miyata, K. Kawahara, S. Tsushima, H. Hironaka, H. Takafuji, M. Rahman, S.A. Ahmad, M.H.S.U. Sayed, M.H. Faruquee: J. Engineering Geology, 60, pp. 323-331 (2001)

11. M. Miyatake, H. Yokota, K. Tanabe, S. Hayashi: Mizukankyou Gakkai, 32, pp. 495-500 (2009)

12. W.R. Cullen and K.J. Reimer: Chem. Rev., 89, pp. 713764 (1989)

13. R. Bentley and T.G. Chasteen: Microbiol. Mol. Biol. Rev., 66, pp. 250-271 (2002)

14. S. Wang and C.N. Mulligan: J. Hazardous Materials, 13, pp. 459-470 (2006)

15. S.M.A. Islam, K. Fukushi, K. Yamamoto: Biotechnol. Lett., 27, pp. 1885-1890 (2005)

16. M. Miyatake and S. Hayashi: Shigen Kankyou Kougaku, 56, pp. 153-158 (2009) 